\title{
Structural insight into the south Ryukyu margin: effects of the subducting Gagua Ridge
}

\author{
Philippe Schnürle ".". Char-Shine I.iu ". Serge E. Lallemand ${ }^{\text {h }}$. Donald L. Reed

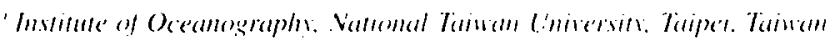

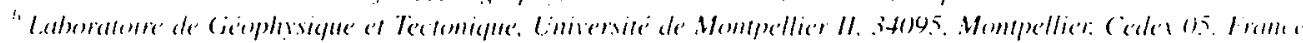

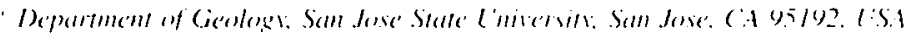

Accepled 19 November 1907

\begin{abstract}
This study presents three multi-channel deep seismic reflection profiles localted in the south Ryukyu margin between $122^{\circ} 30 \mathrm{E}$ and $123^{\circ} 30^{\prime} \mathrm{E}$. where a N-S-trending oceanic ridge. the Gagua Ridge. is entering the subduction /onc. for the purpose of examining the effects of ridge subduction on structures of the forearc region. Structural features which correspond to different stages of the oblique ridge subduction are observed. Fast of 123\% a short-lived sequence of indentation. tumneling. then resumption of frontal accretion occurred in the accretionary wedge (the Yacyama Ridge) as the subducted portion of the (iagua Ridge swept the overriding Ryukyu margin from below along the northuesterly convergent direction. Under the forealre basin. the subducted portion of the Gagua Ridge is upliting the are hasement to form the Nanao Basement Rise which separates the sedimentary strata of the Nanao and Gatst Nanao foreare hasins. Results from this sudy suggest that the oblique subduction of the Gagaa Ridge has not only affected accretionary wedge structures hut also the arc hasement of the south Ryukyu margin. 1998 Elsevier Science B.V. All rights reverved.
\end{abstract}

Kevwords: Ryukyu Trench: West Philippine Basin: Galgua Ridge subduction: Taiuan

\section{Introduction}

The Ryukyu margin forms the northwestern boundary of the Philippine Sea plate and the Chinese continental margin (Fig. 1). The Ryukyu Island Arc extends over $1200 \mathrm{~km}$ between Kyushu (Japan) and Taiwan. Along the Ryukyu Trench, the subduction has been active since the Late Cretaceous (Le Pichon et al.. 1985). At its southwestern extremity, the Ryukyu subduction zone terminates in the Taiwan collision zone. The geology of the southern Ryukyu Islands

Corresponding atuthor. Fax: $8 \times 623626092$. is characterized by high-pressure metamorphic rocks. Eocene volcanics and limestone. and Lower Miccene sediments (Kiraki, 1986), while the istand of Taiwan was formed during the collision of the Luzon volcanic arc and the Chinese passive margin in the last 5 million years (e.g. Ho, 1986; Teng, 1990). The present plate boundary hetween the Eurasia and the Philippine Sea plates passes from the Manila Trench. south of Taiwan, to the Ryukyu Trench. east of Taiwan. through the Taiwan mountain belt. Within this collision zone. thrusts are accommodating the shortening between the two plates at a rate of $7.1 \mathrm{~cm} / \mathrm{yr}$ in a direction of N308 (Senoct al. 1993). 


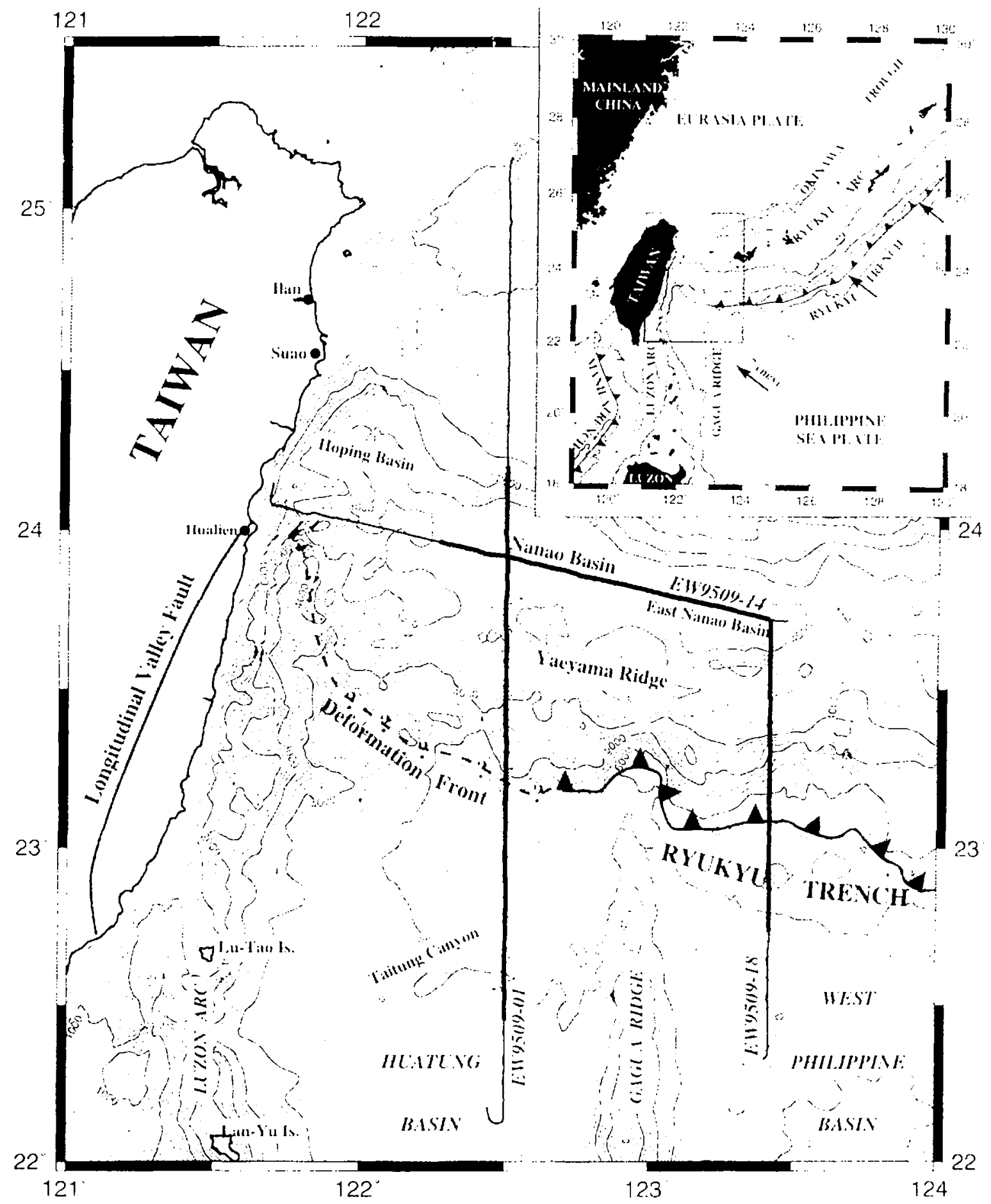

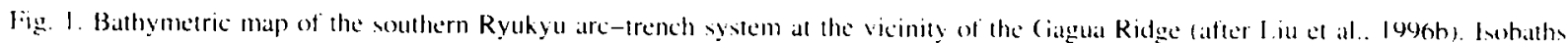

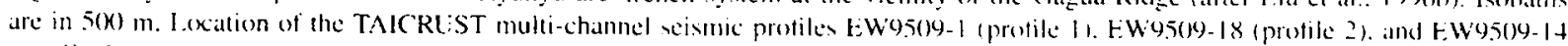

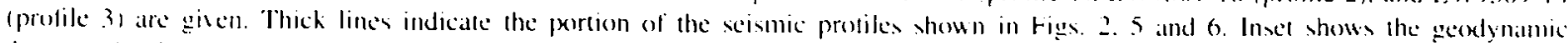

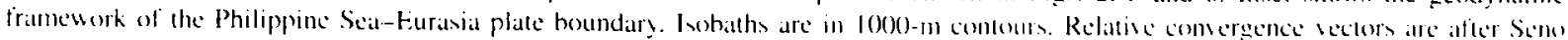
('t al. (1993). Map is generated using GiMT (Wescel and Sinith. 1995). 
Offshore calst Taiwan, a 4()-6()-km-wide acceretionary wedge. the Yacyama Ridge. forms the toe of the convergent Ryukyu margin. A series of 3040-km-wide foreare basins were formed between the growing Yareyama Ridge and the southern flank of the Ryukyu Are basement (Fig. 1). Typical convergent structures of the Ryukyu margin extend westward to about 122030' E (Liu et al.. 1996a). Further west, the deformation front connects the western end of the Ryukyu Trench at $23^{\circ} \mathrm{N}$ to the northern end of the Longitudinal Valley fault near the east coast of Taiwan at $24^{\prime \prime} \mathrm{N}$. Along this northward-bending deformation front. relative convergence is extremely oblique (Fig. 1). Frontal accretion is not active in this portion of the accretionary wedge (Lallemand el al.. 1997$)$. and VW . SE-trending strike-slip faults are observed in the accretionary wedge (Liu el al.. 1996a).

Just east of this bend. the N S-trending Gagua Ridge is being subducted beneath the Ryukyu Trench atong 123" $\mathrm{K}$. als a distinctive re-entrant is observed al where the Gagual Ridge intersects the Yacyama Ridge (Fig. 1). The Gagua Ridge is an aseismic ridge about $2 \mathrm{~km}$ high and $25 \mathrm{~km}$ wide. extending from the northeastern corner of Luzon Island to the Ryukyu Trench (Fig. 1). The marine magnetic sludy of Hilde and Lee (1984) seems to suggest that this ridge is related to a fracture zone. However, the true origin of this ridge is not known yet. Due to its size and continuity, this ridge separates the western-most portion of the Philippine Sea plate, i.e. the Huatung Basin, from the West Philippine Basin. Most of the sediments supplied from the Taiwan mountain belt have been deposited in the Huatung Basin, with the Ryuksu Trench being the only conduit for transporting the sediments across this ridge to the cast. resulting in a bathymetric difference of about $1000 \mathrm{~m}$ between the West Philippine Basin and the Huatung Bisili.

Three multi-channel seismic reflection profiles collected during the TAICRUST survey in the south Ryukyu marsin provide details of the foreare deformation cilused by the subducted Gagua Ridge. In this paper, we present the analyses of these three seismic protiles which are located to the east. west, and north of the Gagua Ridge. respectively (Fig. 1). Structural features which correspond to different stages of the riclge subduction are also discussed.

\section{Data acquisition and processing}

The deep seismic reflection data were collected by the R/V Marerice Euing (cruise E.W9.509) during the TAICRLST survey in August and September of 1995. The TAICRLST project is a seismic imaging program that utilizes deep seismic reflection profiles and wide-angle reflection and refraction datit (recorded by both ocean bottom seismometers and onland seismic stations) to investigate the deep structure and geodynamic processes of the south Ryukyu margin and the Taiwan are continemt collision hone (Liu el al.. 1995). The seismic source uned was a 20 airgun array with a total volume of $8+20$ in " fired all 2()-s intervals. 16 s of seismic reflection data received by a 160)-channel digital streamer $f(H) \mathrm{m}$ in length were recorded. This data set was processed usilly both SIOSEIS and ProMAX seismic processing woliware on two SU'N SPARC20 workstations al the Institute of Occimngraphy. National Taiwan I Iniversity.

Vavigation was provided by differential GPS. using data recorded simultaneous onboard the $R / V$ Maturice Eving and at the hase sattion all the Nittional Taiwan (Iniversity, respectively. (6) obtain the most accurate ship positioning datit. Shot locations where further smoothed ower a lot-min time gale and seismic geonetry wals alsigned hased on al 12.5 In common-mid-point (CMP) intersal. Special efforts have been made to derive the hest velocity. information from the seismic reflection data. Along each protile. stacking velocities were interactively analyzed al every lo()th (MP hased on maximum semblance of a 6-CMP super-gather. These velocity picks were then interpolated allong the sea floor to at regular velocity grid with a sacing of 20 CMPs and to ms. Horizon velocity antlyses nere performed in order to optimise the sticking velocity field. Based on the stacking velocity tield. Irue amplitude recovery was applied to correct for spherical divergence attenuation. Then. Q compensation was derived from the interval velecity tield and applied to correct for inelastic frequency-dependent attenuation. Frequency andysis revealed a frequency content centered around $40 \mathrm{H} /$ with 25 (IB offset below $+\mathrm{H}$ \% and above $70 \mathrm{H} \%$ A minimum phase Ormsby band pass filter with comer frequencies of

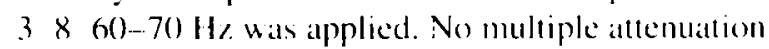
is applied in the sections presented in this study. 


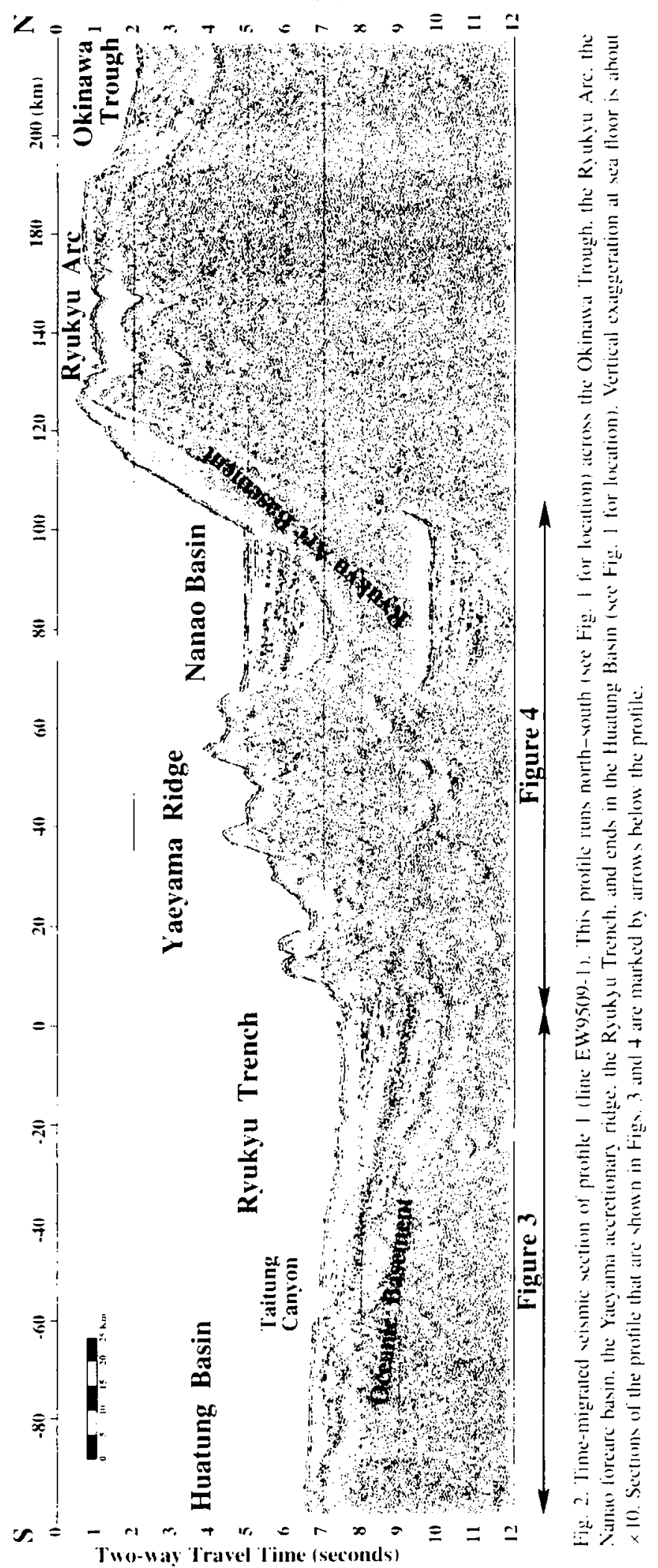


A model-based transform (Naess. 1992) was used to weight (MP gathers and a final stack was produced. Finally. a migration velocity field was constructed based on $85 \%$ lo $75 \%$ of the interval velocities derived from the stacking velocities. and further filtered between $1480 \mathrm{~m} / \mathrm{s}$ and $4000 \mathrm{~m} / \mathrm{s}$. Fast explicit tinite-difference post-stack time migration (Soubiaras. 1992) was performed to generate tinal seismic sections.

Three seismic profiles are analyzed in this study. Protile I (line EW9509-1) consists of 9422 shots with an average shot spacing of $34 \mathrm{~m}$ and a total length of $325 \mathrm{~km}$ (Fig. 2). This profile is located uest of the Gaguat Ridge and is roughly perpendicular to the Ryuhyu Trench. Only the portion south of the Ryukıu Arc is discussed in this study (Figs. 3 and 4). Profile 2 (line EW9509-18) consists of 2875 shots with an average shot spacing of $53 \mathrm{~m}$ and a totial length of $15.3 \mathrm{~km}$. Parallel to profile 1 , it is located aast of the Gagua Ridge (Fig. 5). Profile 3 (line FW9509-14) consists of 4978 shots with an average shot spacing of $37 \mathrm{~m}$ and a total length of $186 \mathrm{~km}$. It runs parallel to the Ryukyu Trench along the axis of the foreare hasin. In this study. we present only the eastern half of the protile (Fig. 6) where the forcarc basin structure is affected by the subducting (ialgual Ridge.

\section{Seismic interpretation}

\section{‥ The Philippine Sea plate}

In the southern portion of profiles 1 and 2 (Figs. 3 and 5. respectively). the Philippine Sea oceanic crust is covered by a thin laver (< 1 s TWT) of sediments. The thickness of the sediments increases progressisely northward to 2.7 . TWT at the trench asis. The top of the oceanic crust on both sides of the Gialla Ridge lowers from 7 s TWT at the outer rise (1) 10 、TW"T at the trench axis. A submarine canyon. the Taitung (anyon. cuts across the southern portion of protile I (Fig. 3). It appears to be located above a fracture within the oceanic plate where a one-second offeet in the aceanic batsement is observed. A second canyon, the Hualien Canyon, intersects this protile near the trench axis. The thick trench fills are mainly derived from the Taiwan mountain belt and transported here hy these two major submarine canyons.
The submarine canyons are not uell expressed east of the Gagua Ridge. Fast of the Gagua Ridge (around $123^{\circ} 30^{\prime} \mathrm{E}$ ), several volcanoes rise from the sea floor in the West Philippine Basin. Profile 2 runs across one of such eylindrical volcanoes thetween -28 and $-38 \mathrm{~km}$ in Fig. 5 ).

A sub-basement reflection is ohserved on profile 1 at about $1.5 \mathrm{~s}$ TWT helos the top of the oceanic basement, between -68 and $-4.5 \mathrm{~km}$. as a high-amplitude long-wavelength reflector (Fig. 3). A similar reflector is imaged on protile 2 between -25 and $0 \mathrm{~km}$ (Fig. 5). This sub-basement reflection could be Moho. However, if it is Moho. dac io the small time interval $(<1.5$, TWT) between the basement reflection and this sub-hascment reflection. the igneous oceanic crust would he very thin fless than $5 \mathrm{~km}$ ). and even thinner cowards the trench. Previously conducted seismic refraction surveys offshore south Ryukyu (Muratuchi et al. 1968) and north Ryukyu (Ludwig el al.. 1973: I wasaki et al.. 1990) show a strong velocity contrast between layer 2 and layer $3(5600-7000) \mathrm{m} / \mathrm{s})$ and an abnormally thin layer 3. Therefore. the continuous sub-basement reflector imaged on our seismic protiles could represent the top of the oceanic latyer 3 whereas the Moho. which should lie less than I TWT deeper. is not well imaged. Further south, this sub-hasement reflection is less clearly imaged hut pros ides al realistic crustal thickness of about $7 \mathrm{~km}$. Crustal velexity structures derived from ocealn bottom seismometer data collected along profile I (Wang et al. 1996) may provide a better constraint on the interpretation of this sub-basement reflection.

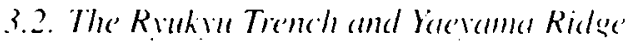

The Ryukyu Trench. at at roughly constant water depth of $6(x) \mathrm{m}$. is cortuous in the study area. The Yacyama Ridge is about $50 \mathrm{~km}$ wide. with depths ranging from $6000 \mathrm{~m} \mathrm{to} 3000 \mathrm{~m}$. It is formed by an imbricated and folded wedge of sedimemts.

Along protile I (Fig. 4). the topography of the Yaeyama Ridge is characterised by ridges. domes and troughs. It is difficult to recognize the precise lociation of the décollement on this seismic section. However, it appears that most of the lerrigenous sediments entering the subduction zone are frontally accreted. The top of the subducting Philip- 


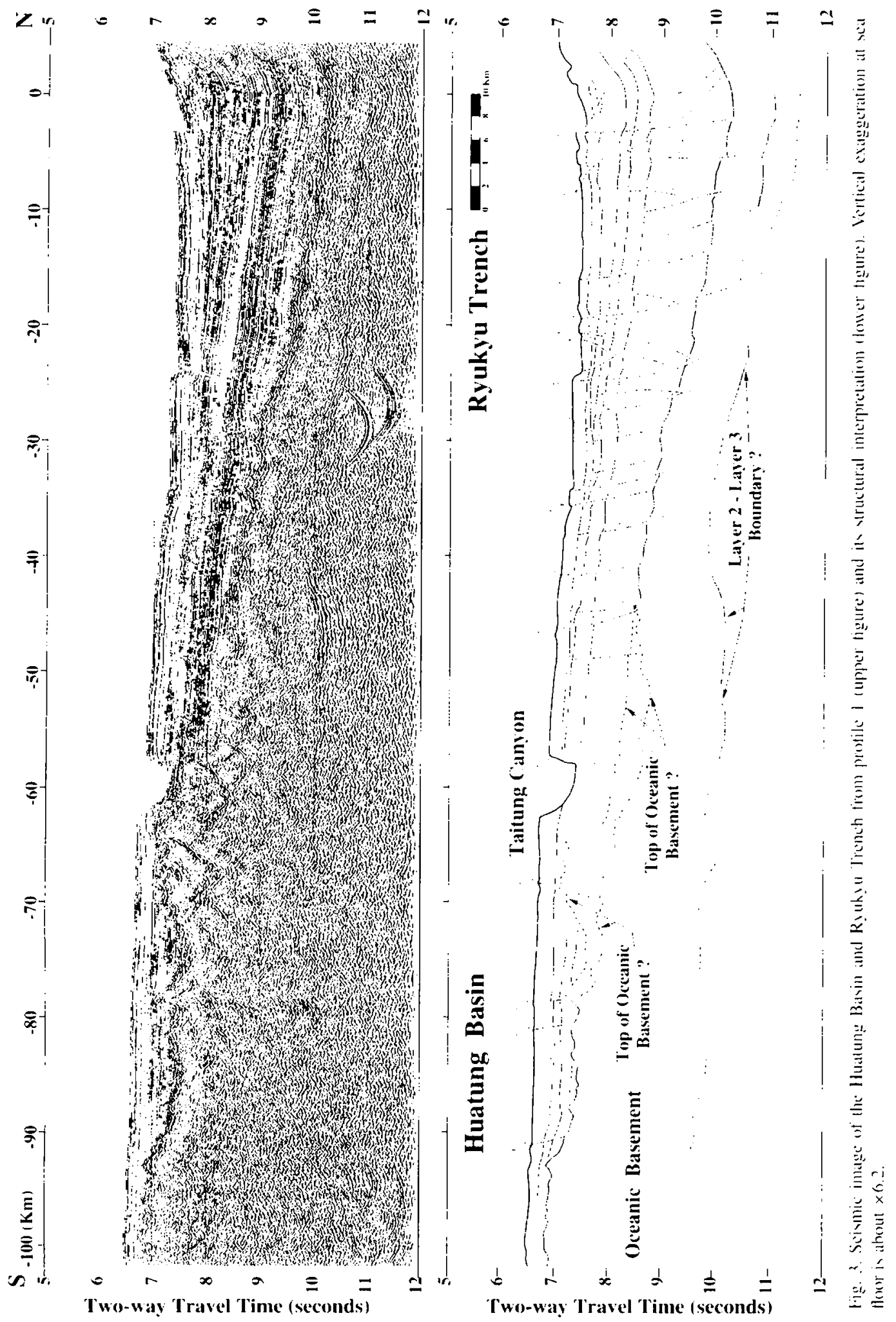




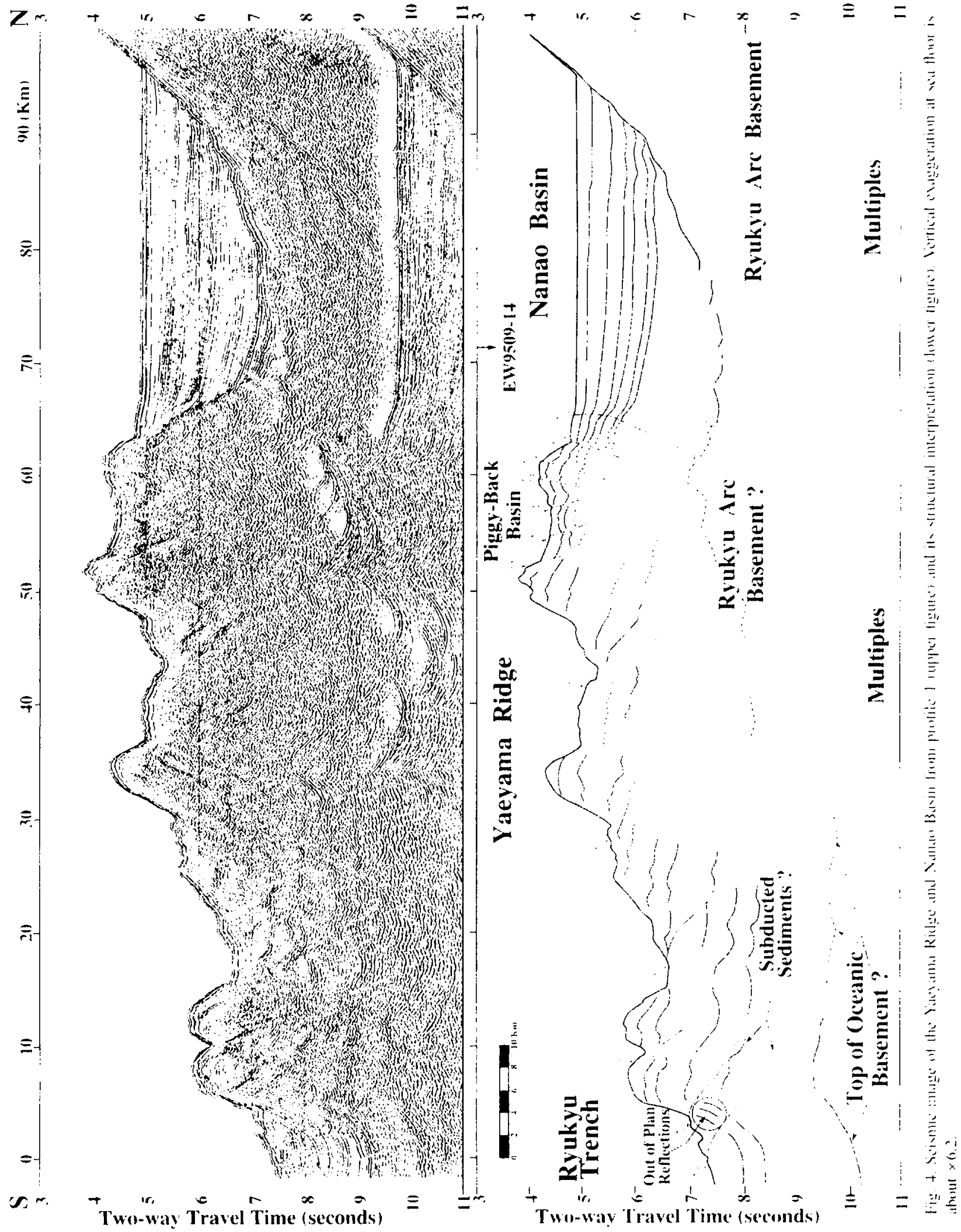




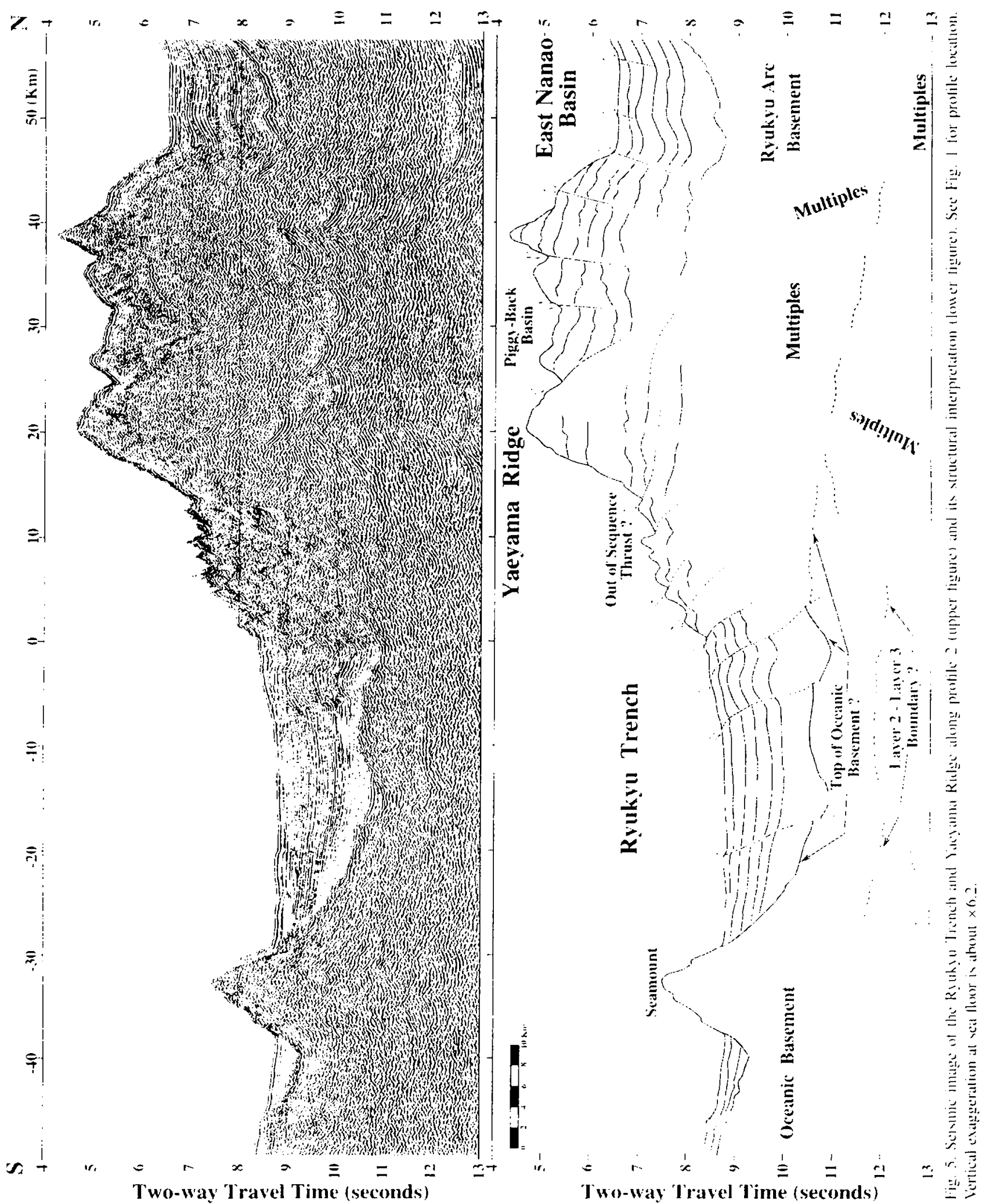




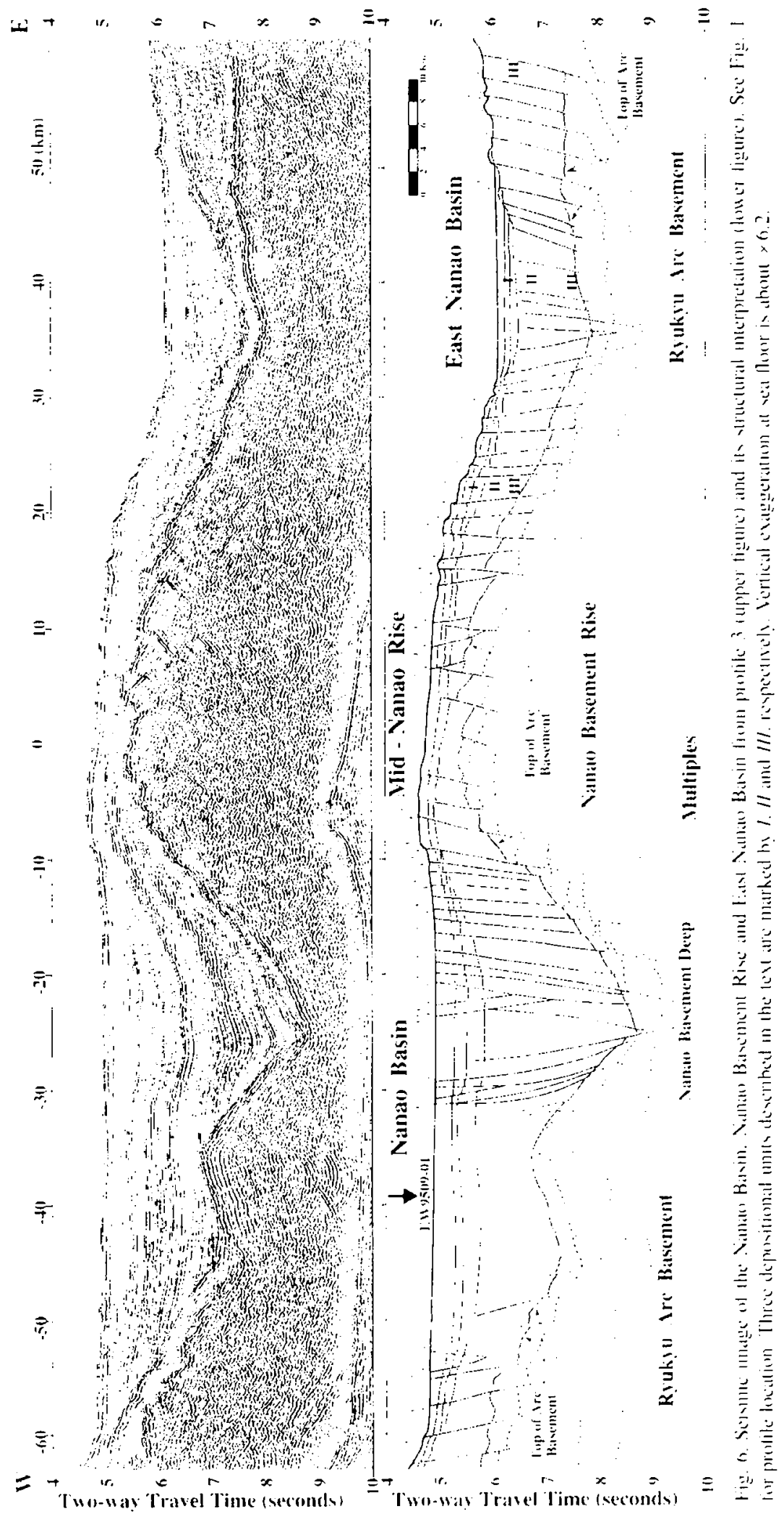


pine Sea plate can be traced at depths of 9.5 to 10) SWT beneath the toe of the Yaeyama Ridge to about $35 \mathrm{~km}$ from the trench axis. then it is masked by the water-bottom multiple. The toe of the overriding accretionary wedge is cut by many thrust faults while back-thrust faults were developed in the northern portion of the aceretionary wedge. $A$ piggy-back basin lies between the frontal thrusts and back-thrusts near the northern edge of the Yacyama Ridge (Fig. 4).

Along protile 2 (Fig. 5). the topography of the Yaeyama Ridge is characterized by a sudden break of the trench slope from 2 to 10 degrees. A major out-of-sequence thrust prohably outcrops at the base of the steep slope. The sediments south of this out-of-sequence thrust are poorly imaged. Again. most of the sediments entering the trench seem to be frontally accreted. The top of the subducting Philippine Sea plate can be traced at depths of 9.5 to I0 s TWT beneath the toe of the Yacyama Ridge to $20 \mathrm{~km}$ from the trench axis. then less clearly at $11-11.5$ s TWT to $40 \mathrm{~km}$. Similar to profile 1 . back-thrusts may affect the northern edge of the Yacyama Ridge.

\subsection{The foreare basin}

Between the Yaeyamal Ridge and the Ryukyu are lies a foreare basin 3()$-35 \mathrm{~km}$ wide (Fig. 1). On the southern side. the foreare basin sediments were trapped against the rear of the Yaeyama Ridge where the development of back-thrusts has progressively thickened the accretionary wedge (Figs. 4 and 5). (On the northern side. the forearc basin is bounded by the southern flank of the Ryukyu Are (Fig. 4). The depth of the foreare hasin here is about $3600 \mathrm{~m}$. Within a horizontal distance of only $26 \mathrm{~km}$, the sea floor ascends to about $1000 \mathrm{~m}$ where it reaches the shelf of the Ryukyu Are (Fig. 2). This slope should be the southern boundary of the Paleoroic-Mesozoic basement of the non-voleanic Ryukyu Are that formed a hack-stop against which the Yaeyama accretionary complex is huilt. Few coherent reflections are imaged within the arc basement.

Profile 3 runs roughly east-west along the axis of the foreare hasin. A basement high in the foreare basin, aligned with the northward projection of the subducting Gagua Ridge, divides the foreare basin into the Nanao Basin and the East Nanao Basin (Fig. 6). Profile 1 crosses the Nanalo Basin near its center $(-.38 \mathrm{~km}$ in Fig. 6). whereas profile 2 surveys the eastern edge of the Last Nanao Basin.

The Nanao Basin is about $75 \mathrm{~km}$ long. Its maximum sediment thickness is about 4 s TW"I (fïg. 6). In the western half of the Nanao Basin, sediments are almost undeformed with continuous parallel reflec tions lying unconformably on the foreare hasement. The basement shows a double stepwise arrangement: the basement depth drops from 5.7 to $7.2 \mathrm{~s}$ TWT in the western part of the Vanao Basin. then deepens again from 7 to 9.2 s TWT near the center of the Nanao Basin where the basement reaches its deepest point (called the Nanao Basement Deep). Several conjugate normal faults cut the entire sedimentary sequences down to the Nanao Basement Deep. East of the depocenter, the basement rises (o form a structural high (called the Nanao Basement Rise) which separates the Nanao Basin from the Fast Nilnao Basin. Sediments are lying conformably on lop of the basement. Vumerous westward-dipping normal faults cut both the Nanao Basin strata and the foreare hasement.

The Nanao Basement Rise is composed of eastdipping tilted blocks covered by 0.7, TWT of recent sediments (Fig. 6). Ilowever, few coherent reflectors are imaged within the basement rise and its precise structure is difficult to see. Eastward. the basement progressively deepens into the Rast Ninao Basement Deep located in the center of the East. Nanao Basin.

Unlike the Nanao Basin which comsists of mainly turbidites from the Taiwan mountain belt, the last Nanao Basin shows a more complicatted depositional history. Three different depositional units cian be recognized (Fig. 6). The oldest unit (unit III). lying on top of the forcarc basement. consists of a series of west-dipping layers that thins from 1.2 s TWT al the castern end of the profile to 0.5 s TWT in the center of the East Nanao Basin. then progressively vanishes toward the west. Above his depositional unit lies at sequence of sediments (unit II) with a similar seismic signature as the Nanao Basin turbidites. In the eastern part of the bassin. this sequence is relatiscly flat and cut by several normal faults of small cumulative throw. Its thickness reaches 1.5 s TW"I in the center of the East Nanao Basin. Further to the west. this unit is tilted towards the east and cut by numer- 
ous east-dipping normal faults as they slide down the Nanaw hasement rise. The most recent sedimentary unit (unil I) is tiat and undeformed.

\section{Discussion}

Topographically. the Gagua Ridge appears 10 end in the Ryukyu Trench. However, a re-entrant of 18.5 $\mathrm{km}(20 \mathrm{~km}$ wide) attests that a portion of the Gagrua Ridge has already been subducted. Newly acquired seismic data confirm that the Cagua Ridge does extend continuously northward underneath the thick trench fill (Char-Shine Liu. unpublished seismic dati. 19977. In the study area, the Ryukyu Trench axis is oriented between $N 270^{\circ}$ and $N 280^{\circ}$ while the relative convergence rate between the Philippine Sea and turasia plates is about $7.1 \mathrm{~cm} / \mathrm{yr}$ in a direction of $\mathrm{N} 308^{\circ}$. Given the high ohliquity $\left(>50^{\circ}\right)$ of the plate convergence here. the subducted portion of the Gagua Ridge should have progressively crept northwestward under the Yaleyama Ridge east of $123^{\circ} \mathrm{F}$. Ridge subduction has been extensively documented in the literature (e.g. Fryer and Smoot. 1985: Lonsdale. 1986: Lallemand and Le Pichom, 1987: Collot and Fisher. 1989: Lallemand et al.. 1990): Von Huene and Scholl. 1991). Lallemand et al. (1994) descrihed the processes related to subduction of an asperity in the folkwing four stages (Fig. 7 ).

(i) Initial stage. The overriding plate is assumed to behave as a non-cohesive Coukmb wedge which slides frictionally over a rigid base the suhducting platel. This wedge obeys the critical taper model derived by Davis et al. (1983) and Dathlen (1984).

(b) Indentation of the margin. The subduction of

A) INITIAL STAGE.

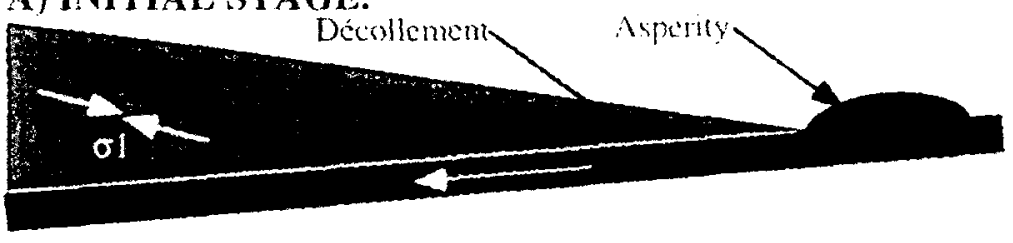

B) INDENTATION OF THE MARGIN.

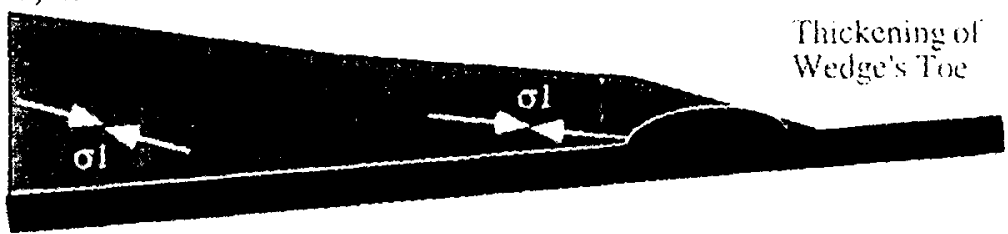

C) TUNELLING PROCESS.

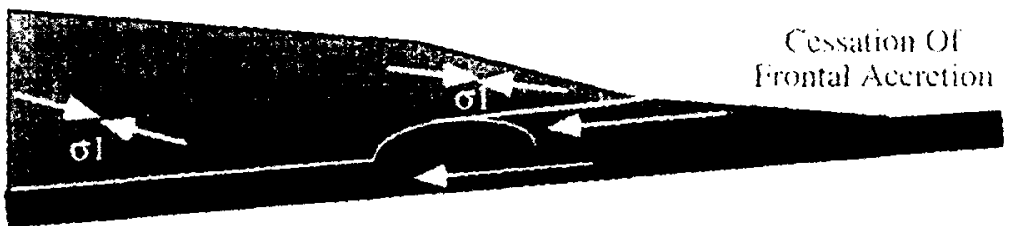

D) RETURN TO A "LOW" DECOLLEMENT.

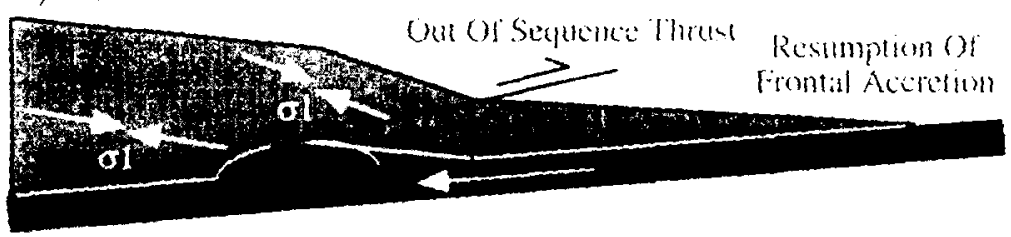

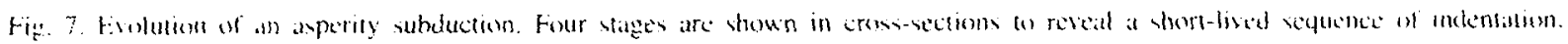

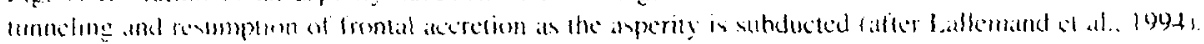


the asperity under the accretionary wedge forces the décollement to move up above the asperity. Thickening of the prism occurs above the landward flank of the asperity. The high friction along this newly formed décollement develops a steep frontal slope above the trailing flank of the asperity.

(c) Tunneling process. While the décollement is forced in this "shallow" position. frontal accretion of the incoming sediments ceases. Those sediments. in the wake of the indentor, are thus easily subducted (Ballance et al.. 1989) beneath the newly formed décollement and its overlying wedge, leaving a reentrant in the deformation front.

(d) Return to a mechanically least resistant 'hasal' décollement. After a certain amount of penetration of the asperity, the décollement jumps down to the vicinity of its initial position. restoring a level of minimum resistance. The older shallow' décollement is fossilized in the form of an out-of-sequence thrust. Frontal accretion then resumes.

The observed structural differences between protile 1 and protile 2 thus can be clarified. The overall shape of the Yaeyama Ridge is a typical accretionary wedge built by imbrication of frontal units during the subduction process. The internal structures along protile 1 consist of seaward-verging anticlinal ridges bounded by arcward-dipping thrusts that express the accretionary nature of the lower slope. In the northern extension of the Gagual Ridge, the re-entrant in the Ryukyu Trench and the thickened Yaeyama Ridge. as observed on the hathymetric map (Fig. 1). are characteristic of the cessation of frontal accretion as the décollement migrates upward above the subducted portion of the ridge. The sudden change in the steepness of the lower trench slope along profile 2, between 13 and $20 \mathrm{~km}$ from the trench. marks the outcrop of the elevated décollement. However. frontal accetion within the incoming sediments appears to have resumed on this seismic profile. attesting to the fact that the decollement has returned (1) a basal position. The shallow arcward-dipping out-of-sequence thrust which crops out at the hase of the cliff can thus be interpreted as the past alctivity of a "high" décollement inherited above the subducting ridge. The newly accreted units are underthrust beneath the out-of-sequence thrust. The arcward extension of this thrust is unclear on the seismic section.
The basement high separating the Vanao Basin from the East Nanao Basin is aligned with the northward projection of the (iagua Ridge (Fig. 1). We suggest that the rise of the basement imaged across the axis of the foreare basins is caused by the subducted Gagua Ridge. The onlap pattern of the sediments deposited on the western flank of the Nanao Rise suggests that the uplift is syn-sedimentary. The divergent depositional pattern as well an the offsets along the west-dipping normal faults suggest a steady hasement uplift occurring mainly in the later stage of the hasin infill. The western part of the Nanao Rise is still actively uplifting.

On the eastern flank of the Vanao Rise. the normal faults have affected both the foreare hasement and the overlying eastward tilted sediments. This suggests that the subsidence occurred following the uplift. In the East Nantan Basin. the most recent sediments (unit $\mathrm{I}$ ) are undisturbed. indicating that this area is now back to a stable situation. These oherervations fit very well with the hypothesis that the alre basement was uplifted by the obliquely subducted Gagua Ridge underneath.

Finally. the high obliquity of the plate convergence may result in strain partitioning within the overriding plate (e.g. Fitch. 1972). Strike-slip fitult preferentially occurs along the contact between the accretionary wedge and the consolidated back-stop (the are basement). as has been described along the Mentawai Fault off Sumatra (Diament el al.. 1992). The trenchward extension of the are hasement. elearly imaged underneath the Nanao Basin. is not well constrained under the aceretionary wedege on our seismic profiles. The back-thrusts affecting the northern edge of the Yaeyama Ridge might provide a natural slip plane for a high-ingle shealr some (Figs. 4 and 5 ).

Furthermore. we can see from firg. I that the Fast Nanato. Nanato, and Hoping foreare hasins lic with stepuise northwestward offects. correlating to the kinks in the bathymetric contours atong the southern flank of the Ryukyu Are. The opening of the Okinawa Trough back-are system might he responsible for this southward stepwise pattern of the southern flank of the Ryukyu Are (Hsu et al.. 1996). These observations may also imply that a much wider part of the Ryukyu matrgin accommodates the oblicpue subduction. 


\section{Conclusions}

Multi-channel seismic reflection protiles and bathymetric data in the south Ryukyu margin reveall the complicated nature of the foreare structures where the Gagua Ridge is being subducted obliquely beneath the Yadeyama Ridge. The prominent re-entrant developed at the toe of the Yacyama Ridge where the Giagua Ridge enters the Ryukyu Trench. shows that the indentation process is active al the present time. The analyses of two $N$. S-trending seismic profiles located on either side of the Gagua Ridge suggest that the out-of-sequence thrust observed in the frontal portion of the Yacyama Ridge on the seismic section to the east of the (jagua Ridge might be formed due to the passage of the Cialgua Ridge underneath the accretionary wedge following the northwesterly direction of plate convergence. The uplift of the foreare basement which separalles the Natnao and East Nanao basins to the north of the re-entrant. logether with the depositional and structural patterns of the forearc basin stratia, suggest that at least a $1(0) \mathrm{km}$ section of the Gaguat Ridge has been subducted. and the ridge hals kept its north south-trending configuration underneath the foreare region of the south Ryukyu margin.

Due (o) the high obliquity of the plate convergence in the south Ryukyu margin, strain partitioning within the frontal portion of the Ryukyu margin mily well be superimposed onto the ridge subduction. In the accretionary wedge, the ridge subduction is likely to have a dominant control. Further north, as the Gianuat Ridece gets deeply buried (ans its depth hecomes large compared to its height). regional tecfonic lorces. such as the Taiwan are-continent collision oceurring just to the west of the study area and the opening of the (Okinawa Trough back-are basin. should all be taken inte aceount when examining the structures of the south Ryukyu margin.

\section{Acknowledgements}

Wi: would like to thank both the crew and technical personnel of the R/V Marrice Eving. cruise EW 9509 . for their efforts in acquiring these excellent diatil despite the visits of five typhoons. G.F. Moore helped a great deal in showing us how to use the ProMAX seismic data processing system.
Discussion with G.F. Moore and N. Lundherg during the EW9509 cruise and with J. Malavicille. J. Angelier. $M$. Fournier and S. Dominguez during the ACT cruise have improved our understanding of the regional tectonic structures. J.-C. Sibuet and S.-K. Hsu provided indispensable information on the opening of the Okinawa Trough. S.-Y. Liu has compiled the hathymetric maps used in this paper. Comments made by $\mathrm{E}$. Fluch. W. Mooney and an anonymous reviewer have improved the quality of this paper. This study presents part of the results of the TAICRLIST project jointly funded by the Vational Science Council. R.O.C. (orants NSC8.3-(0209-M-0)2A-031Y. NSC83-050)1-

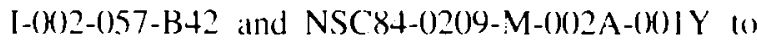
(.-S. Liu) and the National Science Foundation. L.S.A. (grant (OC1994-1658.3 10 I). Reed, N. Lundberg and (G.F. Moore).

\section{References}

Ballance. P.F. Sholl. D.W.. Vallier. T.L... Sicwenson. A.I. Rban. 11.. Her/er. R.H. 1989. Subduction of a late cretacesus scamount of the Louisille Ridge at the Tongat Trench: a model of mormal and accelerated tectonic comion. Tectonics is 15. $953-402$

Collot. I. Y.. Fivler. M.A. 1989. Formation of the foreare hasin. b collision hetween seamounts and accreliomary wedges: an cxample from the new Hebrides island are (ieoloes 17.930) 9.34

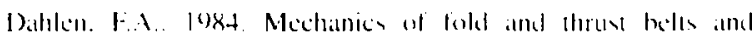

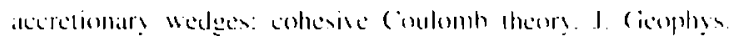

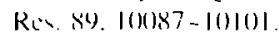

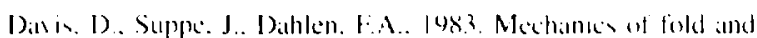

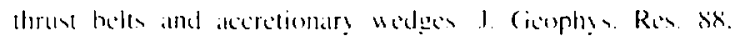
11531172

Diank'nt. M.. Harjonn, H.. Karta. K.. Deplus. ('. Dibrin. D).

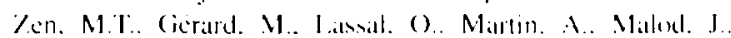

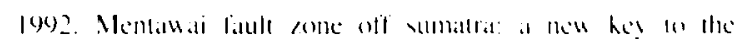

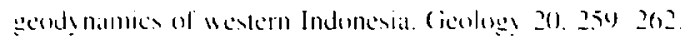

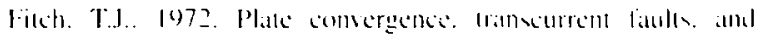

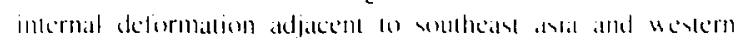
Pacilic. I. (icophus. Res. $771231,4+32+400$.

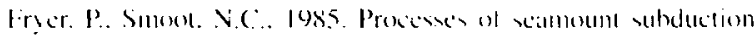

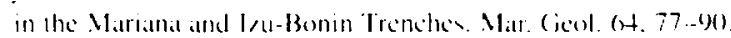

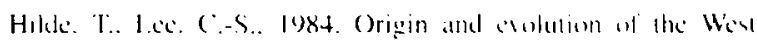

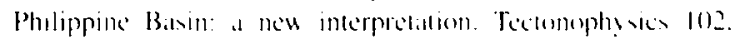
85104

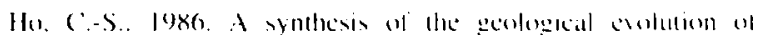

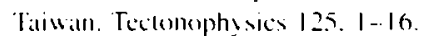

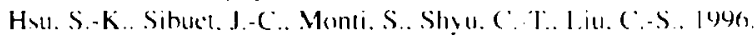
Tramsition between the Ohinama Trough hachare exlensiom

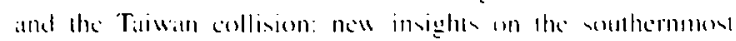


Ryukyu subduction zone. Mar. Geophys. Res. 18. 163-187

Imasaki. T.. Hirita. N.. Kanazawa. T. Melles. J.. Suyehiro. K.. Urahe, T., Möller. I... Makris. J., Shimamura. H.. 1990. (rustal and upper mantle structure in the Ryukyu Island Are deduced irom deep seismic sounding. (ieophys. J. lnt. 102. 6.31-6.51.

Kiraki, K. 1986. Cieology and lectomics of the Ryuky Islands. Tectonophysics 125. 193-207.

Lallemand. S.L.. I.e Pichon. X.. 1987. Coulomb wedge model applied to the subduction of seamounts in the Japan Trench. Geology 15. 1065-1069.

1.allemand. S.F.. von Huene, R. ('ulotti. R. 1990). Subduction of the Daiichi Kashima seamount in the Japan Trench. Tectonophysics 160. 231-247.

Liallemand. S.F... Schnürk. P.. Malaricille. J.. 1994. Coulomb theory applied to accretionary and non-accretionary wedece: possible caluses lor fectonic erosion and or fromal accrelion. J. Geophys. Res. 99 (B61. 12033 12055.

Lallemand. S.I:. 1.iu. C..S.. Font. Y.. 1997. A kar faull boundary between the Taiwan orogen and the Ryukyu subduction ane. Tecionophysics 274. 171-190.

I.c Pichon. X.. Huchon. P.. Barricr. H.. 1985. (icoide and crolution of the wescern margin of the Pacific Ocean. In: Nasu. N. (lid.). Formation of Actice Margins. Terra Publ.. Tokyo, pp. $3+2$.

l.iu. ('.-S.. Reed, D.L... Lundberg. N.. Meore. (j.I.. McInlonh. K.I). Nahamura. Y.. Wang. T.K.. (hen. T.H. Lilllemaund. S.. 1995. Decp seismic inlaging of the Taiwan arc-continent collision ance. EOS. Trans. Am. Ciecophys. Union $761+6 \%$. $F(0,35$.

Litu. C.-S.. L allemand. S.L... Lin. S.-J.. 199(ra. Structural charaleceristic: and possible boundary between the Taiwan collision ane and the Ryukyu arc-trench system. In: Proceedings of the ceological Symposium in Menory of Prof. T.-P. Yen. Nitional Central Lniversity. Chung-Li. Taiuan. Pp. 267275.

l.iu. C.-S.. Liu. S.-Y.. Song. (i.-S.. Shyu. C.-T.. Yu. H.-S.. Chiuu.
L..-Y.. Wanle. ( .-S. Karp. B.. I 990 h. Digital hathymetry datid oftshore Tarisan. 1996 Annu. Meet (icol. Sor. China. Pron. Absir. pp. 420) +25 .

l.onstale. P.I. 1986. A multiticam recomndinsance of Tongea Trench axis and its imersection with the lonisville ciuyen Chain. Mar (icophys. Res. 8. 295327.

I.udwig. W. Murauchi. S.. Ien. N.. Bull. P.. Holla. H.. Ewing. M.. Asanumba. T.. Yoshii. T. Sakajiri. N.. 1973. Structurc of adst China Seat-West Philippine margin off southern Ky ushu. Jatpatm. J. (iosphys. R心. 78. 2526-25.36.

Muratuchi. S.. Den. V.. Asana. S.. Holta. H.. Yoshii. T.. Asanumba.

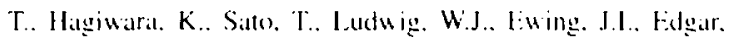
… Houle. R.L:.. 1968. Crustal srocture of the Philippine Sca. J. (icophlys. Res 73. 31433171.

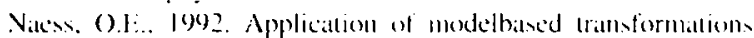
lor scismic interpretational analysis. lirst Break 10. 31.3 322.

Seno. T.. Stcin. S.. (iripp. A.E. 1993. A model for the motion of the Philippine Sca Plate with NIVEI.-1 and geologereal datta. J. Cieophy. Res. 98. 17941-17948.

Soubaras. R. 1992. Lxplicil 31) migration using cyuripple polynomial expansion and Laplaciatn ynthesin. SECi Annu. New. Expanded thesr.. pp. 905-.90)8.

Teng. L..-S. 1990. (icolectonic evolution of the late cenoesole are continent collision in Taiwan. Teconnophysics 18.3. 57-76.

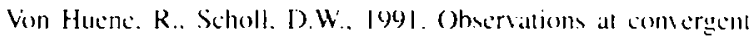
margins concerning xediment subduction. subduction crosion. and the grouth of combinemal crust. Ret. (icoplyse. 29. 279) 316.

Wang. T.-K.. Mclntosh. K.. Nakamura. Y.. L.iu. ('-S.. 1996. ()BS refraction sursey and imaging offshore cascern Taisuan. fos. Trans. Anr. Geophys. Linion 77 (46), 1720 .

Wescel. P. Smblh. W.11.1. 1995. The Cieneric Mapping Towl (GMT) versien 3.1). Technical Relierence and cookhouh. SOESTYNONA. 